\title{
NO RIGHT TO BE SAFE: JUSTIFYING THE EXCLUSION OF ALBERTA FARM WORKERS FROM HEALTH AND SAFETY LEGISLATIONS
}

\author{
BOB BARNETSON \\ Associate Professor of Labour Relations. \\ Faculty of Humanities and Social Sciences, Athabasca University. ${ }^{1}$
}

\begin{abstract}
Alberta remains the only Canadian province to exclude agricultural workers from the ambit of its occupational health and safety laws. Consequently, farm workers have no right to know about workplace safety hazards and no right to refuse unsafe work, thereby increasing their risk of a workplace injury. This study uses qualitative content analysis to identify three narratives used by government members of the legislative assembly between 2000 and 2010 to justify the continued exclusion of agricultural workers from basic health and safety rights. These narratives are: (1) education is better than regulation, (2) farms cannot be regulated, and (3) farmers don't want and can't afford regulation. Analysis of these narratives reveals them to be largely invalid, raising the question of why government members rely upon these narratives. The electoral rewards associated with maintaining this exclusion may comprise part of the explanation.
\end{abstract}

\section{Keywords}

agriculture, health, safety, policy, Canada

\section{Introduction}

Alberta is the only Canadian province that continues to exclude agricultural workers from the ambit of its occupational health and safety legislation. This exclusion

\footnotetext{
${ }^{1}$ Bob Barnetson teaches labour relations at Athabasca University in Edmonton, Alberta, Canada. His research focuses on the political economy of employment regulation in Alberta as it affected workplace injury as well as child, farm and migrant workers. barnetso@athabascau.ca, www.bobbarnetson.ca
} 
deprives farm workers of safety rights that all other workers take for granted-such as the right to know about hazards and the right to refuse unsafe work-and thereby increases their risk of injury. Criticism of this exclusion mounted during the period 2000 to 2010, with the honorable Mr. Justice Peter Barley highlighting the lack of a clear rationale for this exclusion during a 2008 public fatality inquiry into the death of farm worker Kevan Chandler (Alberta 2008a).

This study uses qualitative content analysis to identify how Alberta politicians have justified this exclusion. Review of legislative debates identifies three rationales (or 'narratives') used by government members of Alberta's legislative assembly to justify the continuation of this exclusion. Analysis of these narratives reveals them to be largely invalid. Rather, these narratives appear to serve as rhetorical devices to sustain an electorally advantageous arrangement between rural Albertans and the government as well as legitimate morally questionable behaviour by employers.

\section{Background}

Most Canadian agricultural workers are covered by occupational health and safety laws (Commission of Labour Cooperation n.d). Such coverage provides workers in one of Canada's most hazardous industries with important safety rights, such as the right to know about the hazards associated with their work. It also gives farm workers the right to refuse unsafe work without fear of job loss. And it empowers the state to monitor occupational hazards and prevent injuries through enforcement activity. This legislative protection has come relatively recently, with British Columbia extending OHS protections to farm workers in 2004, Ontario in 2006 and Prince Edward Island in 2007 (Fairey et al. 2011; Ontario 2011; Prince Edward Island 2007). Elsewhere, Australia and the US include farms within the ambit of OHS legislation, but US standards do not apply to family members and also cannot enforce standards on farms with fewer than 11 employees. In this way, US farm safety regulations apply to only about $10 \%$ farms, which employ about half of hired farm workers (Temperley and Fragar 2010; Runyan 2001).

Alberta remains the only province that excludes most agricultural operations from the ambit of its Occupational Health and Safety Act (Alberta 2001a). This exclusion affects workers directly or indirectly involved in the production of crops through the cultivation of land, the raising and maintenance of animals and birds, and the keeping of bees. Workers involved the processing of food or other products as well as workers in greenhouses, mushroom farms, nurseries, sod farms, landscaping operations and operation involving the raising and board of pets are subject to the Act. Alberta also excludes farm and ranch workers from many statutory rights under its Employment Standard Code and Labour Relations Code. Workers' compensation coverage is not mandatory for farm workers (Barnetson 2009). 
Alberta has a long history of excluding resident and migrant farm workers from protective legislation. At the beginning of the $20^{\text {th }}$ century, farmers lobbied for the exclusion of farm workers from workers' compensation on the basis of cost as well as for wage ceilings (Thompson 1978). Farm workers were excluded from the ambit of Alberta's 1917 Factory Act and the 1922 Minimum Wage Board Act (Leadbeater 1984). Farmers also colluded with one another and with provincial labour offices to set wages (Thompson, 1978). During the 1920s, the United Farmers of Alberta avoided legislation and policy that entailed cost increases for farmers (Leadbeater 1984). In this way, Alberta broadly mirrors the pattern found in Ontario by Tucker (2006, 2012). Danysk (1995) notes that provincial and federal government also made significant efforts to disrupt union organization. In the lead-up to and after the Second World War, with the Social Credit government excluding farm workers from legislation addressing male minimum wages, hours of work, collective bargaining rights and wage security acts (Caragata 1979; Finkel 2012), with this pattern of legislative exclusion continuing after the Progressive Conservative party formed government.

A lack of access to statutory protections is one characteristic of precarious work. Precarious workers experience heightened labour insecurity “...characterized by limited social benefits and statutory entitlements, job insecurity, low wages and high risks of ill health" (Vosko 2006, 4). Broadly speaking, agricultural workers in Alberta exhibit these features (Barnetson 2009). Further, work precarity may limit the willingness of workers to exercise their workplace rights (Bernstein, Lippel, Tucker and Vosko 2006). Despite the demonstrable ineffectiveness of complaint-driven enforcement schemes (Weil and Pyles 2005; Barnetson 2010, 2012a), Alberta continues to rely on this approach which suggests that the exclusion of farm workers from OHS legislations is not the only barrier facing farm workers who wish to exercise safety rights.

This post-war legislative exceptionalism around farm workers reflects Canada's preference of "cheap food" and policies designed to support that outcome (Skogstad 2007). These policies include efforts to supply cheap labour, such as the historical progression of interned citizens, prisoners of war, refugees, coerced aboriginal labourers and, eventually, migrant foreign workers in southern Alberta's sugar beet fields (Laliberte 2006). Waged agricultural workers comprise one (albeit heterogeneous) element of the structure of Canadian agriculture. John Shields (1992) asserts this structure has three distinct tiers: agribusiness (i.e., the suppliers of machinery and chemicals, and purchasers of products) on the top, waged agricultural workers on the bottom, and farmers in the middle. Within this structure, individual producers compete among themselves as they purchase supplies and sell commodities to quasi-monopolies that set prices and limit farmers' market power. In this dynamic, farmers seek (and are compelled) to minimize labour costs to manage the cost-price squeeze created by capital determining input and product prices. In permitting and facilitating this arrangement, the state subsidizes the capital accumulation process by transferring part of the cost of social reproduction (i.e., 
food) to agricultural workers via low wages and workplace injury (Basran and Hay 1988; Skogstad 1979, 1987, 2007; Kelly 1982).

Since 2000, Alberta's OHS exclusion has been the subject of increasing criticism from farm worker advocates and opposition parties (Alberta Federation of Labour 2005, 2008, 2009, 2011; United Food and Commercial Workers 2010). Criticism of the exclusion dramatically escalated following the death of feedlot worker Kevan Chandler in 2006 and the release of the 2008 public fatality inquiry report into Chandler's death. In this report, Judge Peter Barley recommended "...paid employees on farms should be covered by the Occupational Health and Safety Act, R.S.A. 2000 Ch. 0-2., with the same exemption for family members and other non-paid workers that apply to non-farm employers" (Alberta 2008a, 7). Barley also noted "No logical explanation was given as to why paid employees on a farm are not covered by the same workplace legislation as nonfarm employees" (Alberta 2008a, 6). This criticism occurred in the context of increasing in legal, academic and union attention to the position of agricultural workers Canada, including the growing use of migrant and immigrant labour, the inability of these workers to unionize, and the health and safety of these workers (Faraday, Fudge and Tucker 2012; United Food and Commercial Workers 2011; Otero and Preibisch 2010; Basok 2002).

Concern about the health and safety of farm workers reflects the hazardous nature of farm work. The agriculture industry records among the highest fatality rates of any Canadian occupation (Picket et al. 1999). Data on non-fatal injuries is elusive, but American data suggests farm workers have the highest incidence of workplace fatalities and higher rates of many occupational diseases and injuries (Hovey and Magana 2002; Sakala 1987). These injury rates reflect well known agricultural dangers, such as exposure to hazardous chemical and biological agents, long working days, physically demanding and repetitive tasks, hazardous equipment and livestock, unsafe transportation, inadequate housing and sanitation, and working alone (Hennerbry 2010; Otero and Preibisch 2010; Anthony, Williams and Avery 2008; Arcury and Quandt 2007, Hansen and Donahue 2003; Arcury et al. 2001). Exacerbating these hazards are a lack of training and education and the absence (or non-use) of personal protective equipment (Verduzco and Lozano 2003; Quandt et al. 2006; Moore 2004).

During the period 2000-2010, Alberta's political scene was stable. The Progressive Conservative party formed majority governments 12 consecutive times between 1971 and 2012. The opposition was fragmented and had been largely urban-based and centre-left leaning. Rural constituencies usually elect conservative Members of the Legislative Assembly (MLAs) (Alberta 1997, 2001b, 2004, 2008b). Consequently, the real political contest in Alberta often occurs within PC Party leadership races, as varying shades of conservativism compete for support. At the end of this period, the new Wildrose Party created a far-right opposition party with rural support, particularly in southern Alberta. The 2012 election saw a potentially significant re-alignment, with rural southern Alberta 
electing Wildrose MLAs and urbanites throwing their support behind the relatively progressive Conservative Party. This change may reduce power of rural Albertans, including the farm lobby.

\section{Method}

This study examines the rationale used by Alberta government MLAs to justify the continued exclusion of most agricultural workers from the ambit of Alberta's Occupational Health and Safety Act as well as the validity of this rationale. The research questions are:

1. How have government MLAs justified the continued exclusion of most agricultural workers from the ambit of OHS legislation?

2. Does this justification hold up to close scrutiny?

In answering the first question, this study uses qualitative content analysis to identify the various 'narratives' that comprise the justification of farm workers' regulatory exclusion. Qualitative content analysis focuses on the content and contextual meaning of textual material in order to classify large quantities of text into manageable categories and thereby reveal underlying patterns or themes of a phenomenon (Hsieh and Shannon 2005; Kohlbacher 2006; Krippendorff 2004; Kondracki and Wellman 2002; Morse and Fiel, 1995). The second question is examined through analysis of each narrative with reference to the literature on farm safety and regulation.

The data for this study comprises all statements recorded in transcripts of the Legislative Assembly of Alberta (Hansard) by government MLAs about farm-worker safety between 2000 and 2010. Such data is appropriate for content analysis because it is intended to communicate a message (White and Marsh 2005). This study excludes government policy documents on farm safety. Examples of these documents were reviewed and not found to articulate a policy rationale suitable for analysis. This study also excludes statements by MLAs recorded in print media. A review of such statements revealed they added little new content.

Data collection began with key word searches (farm, agriculture, safety, injury, injured, worker) of Hansard transcripts indices from 2000 to 2010 (inclusive). This yielded 127 potentially relevant passages that subsequent review narrowed to 61 passages containing a statement by a government MLA about farm worker safety. A coding scheme was developed based upon seven explanations for the exclusion evident in the dataset. All passages were thematically coded and sorted by explanation. Synthesizing each category's passages into a coherent narrative resulted in the elimination of one category due to insufficient evidence. Commonalities within the six remaining categories 
resulted in these categories being collapsed into the three narratives that are set out below.

The key weakness of conventional content analyses is that an inadequate understanding of the phenomenon can exclude important categories and thus distort the results (Hsieh and Shannon 2005). Several strategies based on Guba (1981) and Guba and Lincoln (1994) were used to ensure the trustworthiness of this study, including providing a thick description of findings with numerous exemplars has been presented and having a draft reviewed by two knowledgeable practitioners. As per Melrose (2009), the applicability of the results to other jurisdictions is left for readers to decide based upon context and the documentation set out in the narratives.

\section{Narratives Justifying The Agricultural Exclusion}

Between 2000 and 2010, government MLAs used three narratives to justify the exclusion of agricultural workers from OHS legislation:

1. Education is better than regulation.

2. Farms cannot be regulated.

3. Farmers don't want and can't afford regulation.

These narratives are set out below. There is some overlap between the narratives.

\section{Narrative 1: Education Is Better Than Regulation}

One rationale for maintaining the exclusion of agricultural workers from the ambit of the OHS Act centres on the assertion that safety education is preferable to regulation. Throughout the period of study, government members highlighted Department of Agriculture education programs that identified safety hazards and hazard mitigation strategies. Such statements frame the government's role as a provider of information and education rather than as a regulator. As the issue of farm injury became more politically charged after 2005, government members began to explicitly link education with injury reduction. This statement by then-Minister of Agriculture, Food and Rural Development Doug Horner is illustrative:

Mr. Horner: ... Mr. Speaker, what we're doing is an education program. We're trying to make sure that farmers have the right information about what is safe practice and what are some of the issues that they should be aware of on-farm so that we don't have this number of fatalities (Alberta 


\section{6a). ${ }^{2}$}

In effect, Horner is asserting that making information available will reduce farm injuries. This putative relationship bolsters the notion that the state's role in farm safety should be primarily educative. In 2007, then-Premier Ed Stelmach justified the government's "education" position by asserting that regulation had to be exceptionally intrusive in order to work.

Mr. Stelmach: ... just because we have regulations does not mean that somebody is going to follow them. We have many regulations. We have many laws. We have laws that say that people should stop at a stop sign, and they don't. So what is he saying? That we put a policeman at every intersection in this province to prevent people from not following the rules (Alberta 2007a)?

Subsequent statements broadly follow the assertion that that legislation alone cannot eliminate workplace or farm injuries or fatalities. Consequently, the state is left to emphasize education. Over time, this discourse changes. In 2007, the government's position is that "legislation alone cannot eliminate workplace or farm injuries or fatalities", although presumably legislation might contribute to a reduction in injuries or fatalities. By late 2008, the government's assertions are more categorical: "legislation is not the answer". This categorical denial of the value of legislation is then used to justify both the government's reliance on education and its unwillingness to include farm workers under OHS regulations.

During this change, alternate explanations for why the government will not support regulation emerge. Farms are deemed to be unique workplaces and (some) farmers are said to be resistant to farm safety legislation (see below). These narratives provide further political justification for an education-based intervention. At this point, the "education is better than regulation" narrative is fully formed and subsequent government statements focus on defending this position in two ways. On the one hand, then-Minister of Agriculture and Food George Groenveld implies that regulation would not reduce fatalities:

Mr. Groeneveld: ... I think he brought up a figure of 220 the other day. I'd love to sit down with the hon. member, go through them, and have him

\footnotetext{
${ }^{2}$ It is interesting to note that farm workers are invisible in MLAs' discussion of education. Instead, MLAs assume that various actors (owners, family members, workers) all have the same OHS needs and interests. More broadly speaking, a reviewer (correctly) noted that this study does not address the views of farm workers. These views will be the subject of a planned separate study.
} 
show me where legislation would prevent these accidents. He just has to stop looking at the headlines, and he has to start getting to the facts (Alberta 2009a).

On the other hand, government members such as MLA Robin Campbell suggest that rules can work, but only if those subject to them follow them:

Mr. Campbell: ... Mr. Speaker, I want to talk to you also about safety training and about regulations. Again, I can rely on 30 years of experience. You can have all the safety regulations you want in place, you can have all the safety equipment you want in place, but if people do not use common sense and follow those regulations, they're absolutely worthless (Alberta 2009b).

The apparent contradiction between Groeneveld's assertion that regulation will not reduce injuries and Campbell's (perhaps unconscious) assertion that effective regulation can reduce injuries is never unresolved.

\section{Narrative 2: Family Farms Can't Be Regulated}

A second explanation for excluding agricultural workers from OHS legislation centres on the assertion that the unique nature of (at least some) farms makes regulation unworkable. Beginning in 2006, Horner emphasizes that farms are often mixed-use locations (i.e., homes and workplaces) and thus regulation is somehow inappropriate and/or difficult.

Mr. Horner: ... Farms are unique in that they are work sites, they're homes, and they're places where families live, work, and play, so they can't be treated the same way as a construction site.... We don't have any official way of tracking whether the incident occurred while the person was engaged in a competitive or a recreational aspect or whether it was a farm-productivity activity, in other words working on the farm, so we don't always know if the injury or accident occurred when the person might have been out horseback riding or actually involved in a rodeo (Alberta 2006a).

Horner is correct that some farms are both workplaces and homes and that some "farm" injuries are the result of recreational, rather than occupational, activities. That 
said, not all agricultural work takes place at mixed-use locations and not all mixed-use farms and equipment have recreational potential.

The "farms are also homes" rationale was tested when the government was questioned about why (relatively safe) greenhouses, mushroom farms and nurseries (which operate on mixed-use properties) were under the ambit of the legislation while farms (including relatively dangerous feedlots, which are usually located on single-use sites) are excluded.

Mr. Groeneveld: Well, Mr. Speaker, he understands - I'm certain he understands because I've explained it to him so many times - that farms are unique. Farms are where working families live and they play and they work. Consequently, we've said all along that education and training is where we have to go. I still maintain that you can't legislate common sense (Alberta 2008c).

Groeneveld's inability to explain the discrepancy of regulating relatively safe farms and not regulating relatively dangerous ones casts doubt upon the assertion that farms are not regulated solely because they are mixed-use properties. A variation on this argument is found MLAs' efforts to distinguish between so-called "family farms" and "corporate farms". Stelmach first brings this up in 2007:

Mr. Stelmach: Mr. Speaker, this matter has come up in the House a number of times with respect to protection that farm workers have. There are, of course, those working on family farms and those working on corporate farms (Alberta 2007a).

The nature of the difference between family farms and corporate farms is unclear. Is a family farm a small farm (whatever small means)? Is it also (or alternately) a farm staffed by a family and/or operated as a sole proprietorship? Is a corporate farm a large farm? Or one that employs waged labour? Or an incorporated operation. This difference is never clarified.

Whatever the actual difference is, this difference appears (in the view of MLAs) to meaningfully impact the appropriateness of safety regulation. Subsequent statements further confuse matters. For example, in resisting a call to regulate "big industrial farms that employ dozens of people", Groeneveld notes that most corporate or industrial farms are family-managed businesses:

Mr. Groeneveld: Mr. Speaker, corporate farms or industrial, whatever the hon. member wants to call them, are still managed pretty much by 
families; in fact, in the feedlot industry pretty much entirely. Safety is a personal commitment between employees and employers. They must agree to work together to create a safe workplace. Employees, indeed, are treated like family. That commitment along with education and training makes a huge difference (Alberta 2008d).

In this passage, Groeneveld asserts that, because "(e)mployees... are treated like family", these large, incorporated farms with "dozens of employees" that are "still managed pretty much by families" need not be regulated. This statement suggests that all of the potential differences between a family farm and a corporate farm are, in fact, not differences. According to Groeneveld, corporate or industrial farms are also family farms, regardless of their size, number of employees or legal constitution.

In subsequent questioning, government members altered the basis of the "family farm" exclusion. Then-Minister of Employment and Immigration Thomas Lukaszuk emphasized the "unique" nature of the agricultural labour force:

Mr. Lukaszuk: ... A farming environment is not your regular, standard industrialized environment. You have family members working. You have relatives working. You have neighbours helping neighbours. It is not the standard work environment, so we will be seeking advice from our farming community to tell us what type of assistance they can receive from the Alberta government to make sure that they stay as safe as humanly possible (Alberta 2010a).

This statement asserts regulating a workforce comprising immediate and extended family members and neighbors is inappropriate. Yet, such circumstances exist in many industries subject to Alberta OHS regulation (e.g., restaurants, residential construction, convenience stores) including some forms of regulated agricultural operations (i.e., mushroom farms, greenhouses and nurseries). Furthermore, other jurisdictions (e.g., Australia) successfully regulate farms, some of which have similar labour force characteristics.

Interestingly, only 18 months earlier, Lukaszuk had voted against an opposition motion to introduce amendments to the Occupational Health and Safety Act to protect paid farm workers while continuing to exempt family members and other unpaid labourers. One of the reasons government members gave for not supporting this amendment was because it differentiated workers based upon their family and employment status (Alberta 2009c).

Narrative 3: Farmers Don't Want And Can't Afford Regulation 
Resistance within the agricultural community to the expected cost of safety regulation is the third narrative government MLAs employ to justify maintaining the agricultural exclusion from the Occupational Health and Safety Act. This narrative is sometimes discussed in terms of the economic importance of agriculture, the cost of regulation and the specter of farm bankruptcy. In effect, government members assert the government must trade off worker safety to maintain the profitability of farms.

This "farmers can't afford regulation" portion of this narrative appears three years after a 2003 diagnosis of bovine spongiform encephalopathy (BSE or "mad cow" disease) created significant hardship among cattle producers in Alberta. Consequently, MLAs such as then-Minister of Human Resources and Employment Mike Cardinal were reluctant to impose additional regulations:

Mr. Cardinal: ..., agriculture continues to face many challenges due to the fact that we have to export most of our agricultural products. Therefore, when it comes to agriculture, agriculture cannot afford at this time, because of the status there, to have too many standards imposed on it (Alberta 2006b).

Indeed, in 2006, Cardinal rejected a recommendation to include farm workers under the ambit of the OHS Act from a provincial committee reviewing OHS. His rationale was that the committee did not include representatives of the agricultural community.

Mr. Cardinal: ... if it's going to impact the farm family in particular, we would have to consult the farm families out there and the farm industry to ensure that whatever is put in place does not impact the farm family negatively because the farm families right now, as you know, are challenged. There are a lot of bankruptcies out there. A lot of farm families are close to bankruptcy right now (Alberta 2006c).

Explicit use of “farmers can't afford regulation" fell into disuse after 2006, perhaps reflecting a reduction in economic pressure on farms as restrictions on beef exports were relaxed. Yet the putative threat that safety regulations pose to farms remained a reason to reject regulation until the end of the period under study. For example, in 2008, Lukaszuk indicated:

Mr. Lukaszuk: ... the Minister of Agriculture and Rural Development and I are looking at the (Barley) report, and we will make recommendations 
that achieve two things: keep our farmers safe but also keep them in business because the only way to make sure that a farmer doesn't get hurt is just to put him out of business, and we are not willing to do that (Alberta 2010b).

In this passage, we see Lukaszuk asserting a trade off between safety and economic viability of the farm and, therefore, alternatives to regulation are necessary. In this way, this narrative is linked to the "education is better than regulation" narrative.

Government members have also emphasized the "farmers don't want regulation" portion of this narrative. For example, then-Deputy Premier Shirley McClellan (herself a farmer and former Minister of Agriculture) indicated agricultural producers (i.e., farmers) direct government policy on regulation:

Mrs. McClellan: ... I know that if the producers, in their wisdom not ours, were to come forward in a majority view to the minister of agriculture, he would bring that forward to this table. He represents them extraordinarily well. But I must inform the hon. member, being a part of the agricultural community myself, that they are very independent thinkers, and they like to make their decisions and ask us to carry out policy they believe is in their best interest (Alberta 2006d).

Towards the end of the period under study, the role of the agricultural industry in this narrative has slightly changed. Rather than the agricultural industry being given an effective veto over safety regulation, government members began positing the agricultural industry should shape any regulation.

Mr. Lukaszuk: ... The hon. Member for Edmonton-Riverview will know that the Minister of Agriculture and Rural Development has undertaken an initiative where he will be drawing advice from those they're actually seeking to protect, from farmers, to advise us what is the best kind of coverage that would work for them, whether education would satisfy them (Alberta 2010a).

Again, we see the use of farmers with all agricultural workers, who may have quite different interests than their employers do. To date, such consultations have not resulted in significant change in the government's original position (farmers don't want and can't afford regulation) thus this slight change in emphasis does not fundamentally alter the basic narrative. 


\section{Testing The Narratives}

\section{"Education Is Preferable To Regulation"}

Government MLAs make two assertions when discussing the "education is preferable to regulation" narrative: (1) education is more effective than regulation at reducing injuries and fatalities on farms, and (2) legislation is not effective at reducing injuries and fatalities on farms. Analysis suggests these assertions are invalid.

No studies directly compare the relative efficacy of education and legislation at reducing agricultural injuries. That said, Hagel et al. (2008) found an education-based farm-safety program in Saskatchewan was not associated with observable improvements in farm safety practices, hazards or injury outcomes. A 2003 evaluation of the Canadian Agricultural Safety Program was also unable to substantiate any impact upon fatality of injury rates (Canada 2003). These findings were mirrored in studies of farmers in Colorado and Iowa as well as a national US youth education program (Beseler and Stallones 2010; Rautlainen et al. 2004; Lee, Westaby and Berg 2004).

The broader literature on the effectiveness of education is mixed. Some studies have found positive associations between training and injury reductions (Burke et al. 2005; Waehrer and Miller 2009). Other studies suggest education alone is not effective at reducing injury rates in health care (Tullar et al. 2010; D'Arcy et al. 2011) or logging (Bell and Grushecky 2006) while others report small reductions in construction worker injuries (Kinn et al. 2000; Xuiwen et al. 2004). Overall, there is no evidence that education is more effective than legislation at reducing injuries and weak support that educational programs reduce occupational injuries, with no evidence of this in agriculture.

A practical approach to assessing the impact of educational programs on injury reduction is to examine agricultural injuries in Alberta over time. Unfortunately, Alberta does not collect comprehensive data. What data there is shows little change in farm injury rates between 1997 and 2006 followed by a sharp decline from 2006 to 2009 (Alberta, 2011). ${ }^{3}$ The reliability of this data and the cause of the apparent decline is unclear.

No studies examining the efficacy of OHS legislation at reducing farm injuries were uncovered. Marlenga et al. (2007) suggest that subjecting US family farms to regulation and increasing age restrictions would address most serious injuries experienced by young family farm workers. That said, examinations of OHS compliance on Australian and Irish farms suggests that being subject to legislation does not

\footnotetext{
${ }^{3}$ These statistics should be viewed with caution due to the voluntary and partial nature of the data as well as the absence of controls for changes in the farming population (e.g., the concentration of the livestock industry). The relationship between these stats and farm safety education is unclear as no comprehensive explanation of educational programs or changes exist. Interestingly, the virtual elimination of farm safety education in Alberta during the late 1990s was not associated with any change in these injury rates.
} 
necessarily result in compliance: enforcement is required (Lower, Fragar and Temperley 2011; Finnegan 2007). This accords with the broader literature on OHS legislation (Tompa, Treithick and McLeod 2007). Assuming enforcement occurs, there is a wide body of literature demonstrating it possible to "legislate common sense" and that such regulation is effective and reduces injuries, including mandatory bicycle helmet (Macpherson, 2002) and child car seat use (Farmer et al. 2009), and prohibitions on firearms (Ozanne-Smith et al. 2004; Kapusta et al. 2007), domestic violence (Dugan 2006), and impaired driving (Asbridge et al. 2004; Mann et al. 2001).

Adequately enforced legislation does appear to reduce injury. Indeed, for this reason, the government of Alberta has enacted OHS legislation in all other industries. There is no evidence that this dynamic does not operate in agriculture. In fact, the government has subjected portions of the agricultural industry to OHS legislation. Advocating a demonstrably ineffective "education-only" approach to reducing agricultural injuries calls into question the validity of the government's assertion that "any time we have a farm fatality or a farm accident, it's one time too many. Our goal is to have zero" (Alberta 2008e).

\section{"Farms Cannot Be Regulated"}

Government MLAs make three assertions with respect to regulation when advancing the "farms cannot be regulated" narrative: (1) there is a meaningful difference between "family" and "corporate" farms, (2) the presence of family members and neighbours on the farm prevents regulation, and (3) agricultural operations on mixed-use locations cannot be regulated. Analysis suggests these assertions are invalid.

While government MLA often referred to a putative difference between family farms and corporate farms to explain why regulation is not possible or is difficult, they were unable to establish any criterion upon which family farms could be consistently differentiated from corporate farms. ${ }^{4}$ In other instances, MLAs frequently discussed farms in monolithic terms (e.g., "they're places where families live, work and play") in order to explain why regulation was difficult. This repeated inconsistency (farms are different vs. farms are the same) suggests that positing a difference between family and

\footnotetext{
${ }^{4}$ Data about Alberta's agricultural industry that bears upon this prevalence of different types of farms is very difficult to find. In 2006, Alberta had 49,431 farms, a 7.9\% decline from 2001, with farm size increasing by $8.8 \%$. This continues a long-term trend dating back to at least 1961 (Alberta, 2010d). Of these farms, $13.6 \%$ were run as family corporations and $1.4 \%$ as non-family corporations comprise. The remainder were sole proprietorships or other farm types (e.g., community pastures or institutional farms). Approximately $\$ 537.1$ million in wages and salary payments were reported in 2006. Growth in farm size is largely concentrated in farms over 1600 acres. Growth in farm receipts is almost exclusively in farms with gross income of over $\$ 500,000$. Taken together, these changes suggest an increasing numbers of large-scale, capital-intensive farms.
} 
corporate farms is a rhetorical device designed to sidetrack debate, rather than being a real impediment to regulation.

The assertion that the presence of family members and neighbours on farms precludes any regulation is difficult to believe given that every other Canadian jurisdiction as well as other countries (e.g., Australia) regulates farm work. These jurisdictions use several techniques to distinguish family members and neighbours from other workers (although why family members and neighbours do not warrant similar protections is not clear). Ontario, for example, regulates only paid workers (Ontario 2011). While some farms in other jurisdictions may be significantly smaller in area and larger in workforce than an Alberta farm, there is no evidence or logical reason that Alberta's farms are so unique that regulatory approaches from others jurisdictions are completely inapplicable (Veeman and Veeman 2011).

Alberta government MLAs objected to the regulation of only paid farm workers in 2009. The basis of their opposition was the assertion that all workers must have the same rights. Such blanket treatment runs contrary to other Alberta employment legislation which provides different statutory rights to different worker groups. Further, the paradoxical effect of refusing to distinguish among groups of farm workers (in order not to deprive any group of their rights) is that all farm workers are deprived of statutory safety rights because, in 2010, the government claimed that it can't regulate family members and neighbours in the same way as workers.

The assertion that it is not possible to regulate mixed-use farms is not substantiated. Indeed, Alberta does regulate some mixed-used agricultural operations (e.g., greenhouses, nurseries, and sod and mushroom farms) and other jurisdictions regulate all farms. Further, the degree to which Alberta farms are mixed-use sites is unclear. $^{5}$

\section{"Farmers Don't Want And Can't Afford Regulation"}

Government MLAs assert (1) farmers can't afford regulation, and (2) farmers don't want regulation. The cost of compliance with the Occupational Health and Safety

\footnotetext{
${ }^{5}$ As noted above, there is no reliable source of disaggregated data that clearly indicates the number of industrial-style farms, where the "mixed use" argument might be clearly inapplicable. One former agriculture bureaucrat suggests characterizing the agriculture in monolithic terms (" 49,000 farmers") is an intentional government strategy to avoid regulating industrial-style operations.

Anecdotal evidence of large-scale, industrial-style operations exists. Consider Highland Feeders, a family grain farm incorporated in 1976 east of Edmonton. In 1983, Highland began expanding its cattle operation from 50 head to 36,000 with annual revenue of $\$ 60$ million (Highland Feeder, 2011). Such large-scale operations are increasingly common in livestock. Similarly, grain operations have seen significant consolidation.
} 
Act is unknown and will vary between farms. The absence of a definitive cost analysis of safety regulations in farming raises questions about the veracity of the claim that “...agriculture cannot afford (safety regulations) at this time..." (Alberta 2006d). It should be noted that farmers in other jurisdictions appear able to bear this cost.

One implication of accepting the assertion that regulation is cost-prohibitive is that we also accept its underlying premise: the state should permit businesses that cannot afford to comply with safety standards to avoid them and, thereby, facilitate the transfer of production costs (in the form of workplace injuries) onto workers, their family and society. Enabling farmers to externalize costs via an exemption seems inconsistent with the injury-prevention purpose of OHS legislation. It is also inconsistent with the government's stated goal of having no agricultural fatalities or injuries (Alberta 2008e).

The notion that workers ought to subsidize business costs is not unique to farm safety. In March 2010, then-Minister Lukaszuk froze a planned minimum wage increase affecting $1.5 \%$ of the workforce. "This decision reflects what government feels will both protect jobs during these uncertain economic times and support the economy" (Alberta 2010c, 1). Making low-wage workers absorb inflation-related living costs to protect a few businesses from a $\$ 240$ per worker annual cost increase seems inconsistent with the purpose of minimum-wage legislation.

The main effect of the "farmers can't afford regulation" narrative is that it displaces concern about worker safety with concern about farm profitability. In this way, the desire of agricultural producers (i.e., "farmers don't want regulation") is transformed from a bald statement of self-interest into an unverifiable (but plausible) rationale ("they can't afford it") for maintaining the agricultural exclusion. Similarly, casting agricultural producers in the role of deciding whether and what kind of regulation is necessary is premised on the notion that the profitability of farms is the paramount policy concern. ${ }^{6}$ Overall, this analysis suggested that the "farms don't want and can't afford regulation" is a policy preference rather than a factual statement.

\section{Discussion}

The narratives MLAs use to justify the regulatory exclusion of farm workers from OHS legislation lack validity. The question this raises is: why does the government continue to resist pressure to extend OHS coverage to farm workers? One explanation is that some government MLAs may believe these narratives are valid, despite the flaws

\footnotetext{
${ }^{6}$ It is useful to note concern about farm profitability does not appear to be an impediment in other forms of regulation, such as guidelines about chemical application, handling and disposal, animal health regulations, food safety regulations, water pollution, hazardous waste disposal and the decommissioning of land and surface reclamation of oil and gas sites on farm property.
} 
present in them. ${ }^{7}$ A second explanation is that some government MLAs don't believe these narratives, but find them rhetorically useful in resisting pressure to regulate farm safety. Resistance to regulating agriculture may be motivated by a belief that regulation does not improve injury outcomes and/or an ideological commitment to minimizing regulation. It may also be motivated by the electoral rewards that may be attached to advancing these narratives.

Farmers and other residents of rural communities are threatened by the specter of population loss due to urbanization. Mitigating the effect of this loss depends upon the continued presence of government-operated services (e.g., hospitals, schools and senior homes) as well as retaining agricultural operations (Alberta 2004b). Alberta's government has provided significant support to rural communities (Alberta 2009d), including attracting medical personnel (Alberta 2011b), increasing post-secondary access (Alberta, n.d.), providing broadband internet (Alberta 2011c), providing informational and financial support to rural businesses (Alberta 2011d), and providing hundreds of millions of funding to farmers affected by BSE and other cost pressures (Roy, Klein and Klvacek 2006; Urban Renaissance Institute 2002).

Rural constituencies almost always elect Progressive Conservative candidates to the legislature (Alberta 1997, 2001b, 2004a, 2008a). And Conservative governments have ensured electoral boundaries are drawn so there are a disproportionately high number of rural ridings (Archer 1993; Thomson 2008). Opposing additional regulation is consistent with a symbiotic relationship between Conservative MLAs and rural voters. Some indirect support for this conclusion is evident in third narrative: that an employer does not desire to be subject to OHS regulation is hardly surprising but that farmers are able to actualize this desire is unusual. This suggests they are utilizing some lever to maintain their preferred status in the face of regulatory pressure on MLAs.

These narratives provide politicians with some protection from criticism that they are enabling employers to expose workers to hazards that other workers do not face. These narratives also legitimize employer decisions to trade workers' health for profit. Pairing the assertion that farmers can't afford regulation with the assertion that education provides adequate protection erects a rhetorical shield for employers against public wrath over the issue. In this way, the government is legitimizing employer behaviour that might otherwise be considered unacceptable by the public. These findings are important for two reasons. First, they are one of the first efforts to analyze and contextualize how government MLAs justified a controversial policy. Second, they unpack aspects of the state's role in a capitalist economy to legitimate harmful modes of production.

It is unclear whether granting farm workers basic safety rights will make any significant difference in their safety at work. Alberta regulators note that the low probability of inspection means farm operators who are within the ambit of the OHS Act

\footnotetext{
${ }^{7}$ Informal discussion with bureaucrats suggests the narratives' flaws are well known.
} 
are not highly motivated to comply (Aitkin 2012), a pervasive issue throughout Alberta's OHS system (Barnetson, 2012b). As identified by Bernstein et al. (2006), the precarious nature of farm work may well create barriers (e.g., limited job security and fear of employer retribution) that prevent workers from exercising any rights they gain via statutory inclusion. Even Canadian workers with secure employment have difficulty refusing unsafe work (Gray 2002; Fidler 1985). Further, there is some evidence that Canadian governments are using worker safety rights as a way to transfer responsibility for workplace safety from employers to workers (Gray 2006a, 2006b, 2009). Blaming workers is evident in Alberta's OHS prevention materials (Barnetson and Foster, 2012).

That said, including farm workers within the ambit of OHS legislation is still useful. Possessing rights is a necessary precondition to exercising them. While the number of farm workers who will exercise them alone is likely to be small, possessing such rights gives worker organizations a place on which to hinge demands for compliance and enforcement. That is to say, rather than fighting for recognition of farm worker safety rights, such campaigns can focus on enforcing farm worker safety rights. To the degree that there is political will to do so, including farm workers within the ambit of the OHS Act also allows the government to inspect farms and penalize employers who violate the rules (although realistically, Alberta inspects fewer than 1 in 14 workplaces a year and only sanctions employers in a small minority of cases of serious injury or worker death). That said, inspection of only industrialized agricultural worksites (e.g., feedlots) would be a huge improvement. There is also a normative dimension to granting farm workers safety rights. Farmers may feel moral and/or reputational pressure (especially over time) to meaningfully consider and accommodate farm worker safety. Those who don't comply can then be subjected to political tactics, such as boycotts or public shaming. This may increase the effectiveness of Alberta's emphasis on safety education.

\section{Conclusion}

The purpose of this study was to ascertain how government MLAs justified maintaining the regulatory exclusion of agricultural workers from the ambit of Alberta's OHS legislation and to examine the validity of the rationale(s) used. Content analysis of legislative debates generated three invalid narratives that are used to justify the exclusion. The question this raises is: why do MLAs support maintaining the regulatory exclusion? One explanation is that MLAs may not accept that these narratives are invalid. An alternate (or complimentary) explanation is that these narratives have utility in maintaining the exclusion and thereby realize electoral rewards. That is to say, the Conservative Party may have developed a symbiotic relationship with rural voters and felt compelled to refrain from regulating agricultural employment. More bluntly, the political 
risk associated with regulating farm safety may be seen as higher than the political risk associated with farm worker injury and death.

\section{Acknowledgements}

The author would like to thank Jason Foster (Athabasca University), Kevin Flaherty (Alberta Workers' Health Centre), Douglas Taylor, and several anonymous reviewers for their helpful commentary.

\section{References}

Aitken, L. "Workplace Safety: Innovative Practices and Strategies for Critical Safety Thinking," Work-Leanring Network Seminar Series. March 12. Edmonton. http://www.wln.ualberta.ca/en/ /media/wln/Documents/Events/AitkenFarm_Saf etyNotesMar_12.pdf (27 June 2012).

Alberta, Agriculture and Rural Development, Seeing Success: Increasing Learning Opportunities in Rural Communities. [Edmonton], no date.

Alberta, Office of the Chief Electoral Officer Elections, 1997 General Election Report. [Edmonton], 1997.

Alberta. Occupational Health and Safety Act Farming and Ranching Exemption Regulation. RSA 27/1995 [Edmonton, AB]: Queen's Printer, 2001a.

Alberta, Office of the Chief Electoral Officer Elections, 2001 General Election Report. [Edmonton], 2001b.

Alberta, Office of the Chief Electoral Officer Elections, 2004 General Election Report. [Edmonton], 2004a.

Alberta. MLA Steering Committee on Rural Development, Rural Alberta: Land of opportunity. [Edmonton], $2004 \mathrm{~b}$.

Alberta, Alberta Hansard, 11 May 2006a (Mr. Horner, PC) pp. 1520-1521.

Alberta, Alberta Hansard, 18 May 2006b, (Mr. Cardinal, PC) pp. 1671-1672. 
Alberta, Alberta Hansard, 31 August 2006c (Mr. Cardinal, PC), pp. 1847-1848.

Alberta, Alberta Hansard, 18 May 2006d (Mrs. McClellan, PC), p. 1672.

Alberta, Alberta Hansard, 22 March 2007a (Mr. Stelmach, PC), pp. 294-295.

Alberta, Ministry of Justice, "Report to the Minister of Justice and Attorney General, Public Fatality Inquiry”. [Okotoks], 2008a.

Alberta, Office of the Chief Electoral Officer Elections, 2008 General Election Report. [Edmonton], 2008b.

Alberta, Alberta Hansard, 1 December 2008c (Mr. Groeneveld, PC), p. 2133.

Alberta, Alberta Hansard, 28 April 2008d (Mr. Groeneveld, PC), p. 247.

Alberta, Alberta Hansard, 13 May 2008e, p. 662.

Alberta, Alberta Hansard, 12 March 2009a (Mr. Groeneveld, PC), p. 372.

Alberta, Alberta Hansard, 1 June 2009b (Mr. Campbell, PC), pp. 1444.

Alberta, Alberta Hansard, 1 June 2009c (Mr. Lukaszuk, PC), p. 1442.

Alberta, Department of Agriculture and Rural Development, Alberta's Rural Development Strategy: 2009 Update Report. [Edmonton], 2009d.

Alberta, Alberta Hansard, 30 November 2010a (Mr. Lukaszuk, PC), pp. 1699-1700.

Alberta, Alberta Hansard, 24 March 2010b 9Mr. Lukaszuk, PC), p. 638.

Alberta, Department of Employment and Immigration, Alberta's Minimum Wage to Remain the Same Throughout 2010. [Edmonton] 2010c.

Alberta, Department of Agriculture and Rural Development, Alberta Agriculture Statistics Yearbook 2009. [Edmonton] 2010d. 
Alberta, Farm Safety Council, Farm Injury/Fatality Statistics in Canada, [Edmonton], 2011 http://www.abfarmsafety.com/resources/statistics.htm (October 19, 2011).

Alberta, Agriculture and Rural Development, The Alberta Rural Physician Action Plan website. [Edmonton], 2011 b http://www.rpap.ab.ca/ (28 September 2011).

Alberta, Agriculture and Rural Development, Rural Connections: Community Broadband Infrastructure Pilot Program Approved Projects. [Edmonton], 2011c.

Alberta, Agriculture and Rural Development, Programs and Services for All Audiences. [Edmonton], 2011d. http://www.agric.gov.ab.ca/app52/programsservices Downloaded (28 September 2011).

Alberta Federation of Labour, "End the Drought Farmworkers campaign launched". [Edmonton], 2005.

Alberta Federation of Labour, "Alberta Liberals press for farm labour standards". [Edmonton], 2008.

Alberta Federation of Labour, "Alberta heads down dangerous path with farm worker discimination”. [Edmonton], 2010.

Alberta Federation of Labour. "Minister's silence on farm worker safety unacceptable, says AFL". [Edmonton], 2011.

Anthony, M., J. Williams and A. Avery, "Health Needs of Migrant and Seasonal Farm Workers," Journal of Community Health Nursing, 25 (2008), 153-160.

Archer, K. "Conflict and Confusion in Drawing Constituency Boundaries: The Case of Alberta," Canadian Public Policy, 19(2) (1993), 177-193.

Arcury, T. and S. Quandt, "Delivery of Health Services to Migrant and Seasonal Farmworkers," Annual Review of Public Health, 28 (2007), 345-363.

Arcury, T., S. Quandt, A. Cravey, R. Elmore and G. Russell, "Farmworker Reports of Pesticide Safety and Sanitation in the Work Environment," American Journal of Industrial Medicine, 39 (2001), 487-498. 
Asbridge, M., R. Mann, R. Flam-Zalcman and G. Stoduto, “The criminalization of Impaired Driving in Canada: Assessing the Deterrent Impact of Canada's First per se Law," Journal of Studies on Alcohol, 65(4) (2004), 450-459.

Basok, T. Tortillas and Tomatoes: Transmigrant Mexican Harvesters in Canada (Montreal 2002).

Barnetson, B. "The Regulatory Exclusion of Agricultural Workers in Alberta," Just Labour, 14 (2009), 50-74.

Barnetson, B. "Effectiveness of Complaint-driven Regulation of Child Labour in Alberta." Just Labour 16 (2010), 9-24.

Barnetson, B. “The Validity of Alberta Safety Statistics." Just Labour 19 (2012a), Forthcoming.

Barnetson, B. "Labour and Safety in a Natural Resource Economy," Parkland Institute Oil and Democracy Lecture Series. Edmonton. May 252012 b. http://albertalabour.blogspot.ca/2012/05/labour-and-safety-in-naturalresource.html (June 27, 2012).

Barnetson, B. and J. Foster, "Bloody Lucky: The Careless Worker Myth in Alberta, Canada," International Journal of Occupational and Environmental Health, 18(2) (2012). Forthcoming.

Basran, G. and D. Hay, "Crises in Agriculture in Western Canada: A Theoretical Explanation.” in G.S. Basran and D.A. Hay (eds.), The Political Economy of Agriculture in Western Canada. 41-54, Toronto: Garamond, 1988.

Bell, J. and S. Grushecky, "Evaluating the Effectiveness of a Logger Safety Training Program," Journal of Safety Research, 37(1) (2006), 53-61.

Bernstein, S., K. Lippel, E. Tucker and L. Vosko, “Precarious Employment and the Law's Flaws: Identifying Regulatory Failure and Securing Effective Protection for Workers," in L. Vosko (ed.), Precarious employment. 256-276. Montreal: McGillQueen's University Press, 2006. 
Beseler, C. and L. Stallones, "Safety Knowledge, Safety Behaviours, Depression and Injuries in Colorado Farm Residents, American Journal of Industrial Medicine, 53(1) (2010), 47-54.

Burke, M., S. Sarpy, K. Smith-Crowe, S. Chan-Serafin, R. Salvador and G. Islam, "Relative Effectiveness of Worker Safety and Health Training Methods," American Journal of Public Health, 96(21) (2005), 315-324.

Canada, Department of Agriculture and Agri-Food, Evaluation of the Canadian Agricultural Safety Program. [Ottawa] 2003.

Caragata, W. Alberta Labour: A Heritage Untold. Toronto: James Lorimer and Company, 1979.

Commission for Labour Cooperation, Guide to on-the-Job Health and Safety in Canada. [Washington], no date.

Danysk, C. Hired Hands: Labour and the Development of Prairie Agriculture, 1880-1930. Toronto: University of Toronto Press, 1995.

Dugan, L. "Domestic Violence Legislation: Exploring its Impact on the Likelihood of Domestic Violence, Police Involvement, and Arrest," Criminology \& Public Policy, 2(2) (2006), 283-312.

D’Arcy, L., Y. Sasai and S. Stearns, "Do Assistative Devicies, Training and Workload Affect Injury Incidence? Prevention Efforts by Nursing Homes and Back Injuries Among Nursing Assistants," Journal of Advanced Nursing, (2011) DOI: 10.1111/j.1365-2648.2011.05785.x.

Fairey, D. C. Hanson, G. MacInnes, A. McLaren, G. Otero, K. Preibisch, and M. Thompson, "Cultivating farmworkers' rights: Ending the exploitation of immigrant and migrant farmworkers in BC," Report, Canadian Centre for Policy Alternatives, 2008.

Faraday, F., J Fudge and E. Tucker (eds). Constitutional Labour Rights in Canada: Farm Workers and the Fraser Case. Toronto: Irwin, 2012.

Farmer, P., A. Howard, L. Rothman and A. Macpherson, "Booster Seat Laws and Child Fatalities: A Case-Control Study," Injury Prevention, 15 (2009), 348-350. 
Fidler, R. "The Occupational Health and Safety Act and the Internal Responsibility System." Osgoode Hall Law Journal. 24(2) (1985), 314-352

Finkel, A. Working People in Alberta: A History. Edmonton: Athabasca University Press, 2012.

Finnegan, A. "An Examination of the Status of Health and Safety in Irish Farms," PhD Thesis, National University of Ireland, 2007.

Gray, G. “A Socio-legal Ethnography of the Right to Refuse Dangerous Work.” Studies in Law, Politics and Society 24 (2002), 133-169.

Gray, G. “Ticketing Health and Safety Offenders: a Sociolegal Examination of Ticketing in High-risk Firm Initiatives." Policy and Practice in Health and Safety 4(2) (2006a), 77-93.

Gray, G. "The Regulation of Corporate Violations: Punishment, Compliance and the Blurring of Responsibility." The British Journal of Criminology 46(5) (2006b), 875-892.

Gray, G. "The Responsibilization Strategy of Health and Safety." The British Journal of Criminology 49(3) (2009), 326-342.

Guba, E. "Criteria for Assessing the Trustworthiness of Naturalistic Inquiries," Educational Communication and Technology Journal, 29 (1981) 75-91.

Guba, E. and Y. Lincoln, "Competing Paradigms in Qualitative Research," in N.K. Denzin and Y.S. Lincoln, eds., Handbook of Qualitative Research (Thousand Oaks 1994), 105-117.

Hagel, L., W. Pickett, P. Pahwa, L. Day, R. Brison, B. Marlenga, T. Crowe, P. Snodgrass, K. Ulmer and J. Dosman, "Prevention of Agricultural Injuries: An Evaluation of an Education-based Intervention,” Injury Prevention. 14 (2008), 290-295.

Hansen, E. and M. Donohue, "Health Issues of Migrant and Seasonal Farm Workers," Journal of Healthcare for the Poor and Underserved, 14 (2003), 153-164. 
Hennerbry, J. "Not Just a Few Bad Apples: Vulnerability, Health and Temporary Migration in Canada," Canadian Issues/Themes Canadiens, Spring (2010), 73-76.

Highland Feeder, Our Advantage. [Vegreville], 2011 http://www.highlandbeef.com/index.php?area_id=1002 (23 October 2011).

Hovey, J. and C. Magana, "Psychosocial Predictors of Anxiety Among Immigrant Mexican Migrant Farmworkers: Implications for Prevention and Treatment," Cultural Diversity and Ethnic Minority Psychology, 8 (2002), 274-289.

Hsieh, H-F. and S. Shannon, "Three Approaches to Qualitative Content Analysis," Qualitative Health Research, 15(9) (2005), 1277-1288.

Kapusta, N., E. Etzerdorfer, C. Krall and G. Sonneck, "Firearm Legislation Reform in the European Union: Impact on Firearm Availability, Firearm Suicide and Homicide Rates in Austria," The British Journal of Psychiatry, 191 (2007), 253-257.

Kelly, M. The Economics of Agriculture in Alberta: Selected Issues. Edmonton: Alberta Agriculture, 1982.

Kinn, S., S. Khuder, M. Biscesi and S. Woolley, "Evaluation of Safety Orientation and Training Programs for Reducing Injuries in the Plumbing and Pipefitting Industry," Journal of Occupational and Environmental Medicine. 42(12) (2000), 1142-1147.

Kohlbacher, F. “The Use of Qualitative Content Analysis in Case Study Research,” Forum: Qualitative Social Research. 7(1) (2006), Art. 21 DOI. 10-1.1.1.97.1378.

Kondracki, N. and N. Wellman, "Content Analysis: Review of Methods and their Applications in Nutrition Education," Journal of Nutrition Education and Behavior, 34 (2002), 224-230.

Krippendorff, K. Content Analysis: An Introduction to its Methodology, $2^{\text {nd }}$ Ed. (Thousand Oakes 2004).

Laliberte, R. “The 'Grab-a-Hoe' Indians: The Canadian State and the Procurement of Aboriginal Labour for the Southern Alberta Sugar Beet Industry. Prairie Forum. 31(2) (2006), 305-324. 
Leadbeater, D. "An Outline of Capitalist Development in Alberta," in D. Leadbeater (ed.). Essays on the Political Economy of Alberta. 1-76, Toronto: New Hogtown Press, 1984.

Lee B., J. Westaby and R. Berg, "Impact of a National Youth Health and Safety Initiaitive: Results from a Randomized Controlled Trial," American Journal of Public Health, 94(1) (2004), 1743-1749.

Lower, T., L. Fragar and J. Temperley, "Agricultural Health and Safety Performance in Australian," Journal of Agromedicine. 16(4) (2011), DOI:10.1080/1059924X.2011.605726.

Macpherson A., T. To, C. Macarthur, W. Chipman, J. Wright and P. Parkin, "Impact of Mandatory Helmet Legislation on Bicycle-Related Head Injuries in Children: A Population-Based Study," Pediatrics. 110(5) (2002), 231-235.

Mann, R., S. Macdonald, G. Stoduto, S. Bondy, B. Jonah and A. Shalkh, "The Effects of Introducing or Lowering Legal per se Blood Alcohol Limits for Driving: An International Review," Accident Analysis \& Prevention, 33(5) (2001), 569-583.

Marlenga, B., R. Berg, J. Linneman, R. Brison and W. Pickett, "Changing the Child Labor Laws for Agriculture: Impact on Injury," American Journal of Public Health, 97(2) (2007), 276-282.

Melrose, S. "Naturalistic Generalization," in A. Mills, G. Durepos and E. Weibe, eds., Encyclopedia of Case Study Research (Thousand Oaks, 2009).

Moore, G. (2004). Hand-harvesters of Fraser Valley berry crops: New era protection of vulnerable employees. Vancouver: British Columbia Federation of Labour.

Morse, J. and P. Field, Qualitative Research Methods for Health Professionals, 2nd ed. (Thousand Oaks 1995).

Ontario, Department of Labour, Occupational Health and Safety Act Application to Farming Operations: Frequently Asked Questions. [Toronto], 2011.

Otero, G. and K. Preibisch, "Farm Worker Health and Safety: Challenges for British Columbia”. [Burnaby], 2010. 
Ozanne-Smith, J., K. Ashby, S. Newstead, V. Stathakis and A. Clapperton, "Firearm Related Deaths: The Impact of Regulatory Reform," Injury Prevention, 10 (2004), 280-286.

Pickett, W., L. Hartling, R. Brison and J. Guernsey, "Fatal Work-Related Farm Injuries in Canada, 1991-1995," Canadian Medical Association Journal, 160 (1999),18431848.

Prince Edward Island, Department of Agriculture, Farm Safety Week March 14-27. [Charlottetown], 2007.

Quandt, S., M. Hernandez-Valero, J. Grzywacz, J. Hovey and M. Gonzales, "Workplace, Household and Personal Predictors of Pesticide Exposure for Farm Workers," Environmental Health Perspectives. 14 (2006), 943-952.

Rautlainen, R., J. Lange, C. Hodne, S. Schneiders and K. Dinham, "Injuries in the Iowa Certified Safe Farm Study,” Journal of Agricultural Safety, 10(1) (2004), 51-63.

Roy, D., K. Klein and T. Klvacek, "The Losses in the Beef Sector in Canada from BSE," Canadian Agricultural Trade Policy Research Network Commissioned Paper CP 2006-5. (Guelph 2006).

Runyan, J. Federal laws and regulations affecting farm safety. Washington, National Agricultural Safety Database, 2001. http://nasdonline.org/document/1842/d001777/federal-laws-and-regulationsaffecting-farm-safety.html (27 June 2012).

Sakala, C. "Migrant and Seasonal Farm Workers in the United States: A Review of Health Hazards, Status and Policy," International Migration Review, 21 (1987), 659-687.

Shields, J. "The Capitalist State and Farm Labour Policy," in D. Hay and G. Basran (eds.), Rural sociology in Canada. 246-266, Toronto: Oxford University Press, 1992.

Skogstad, G. "Farmers and Farm Union in the Society and Politics of Alberta," in C. Caldarola (ed.), 223-255, Society and Politics in Alberta. Toronto: Taylor and Francis, 1979.

Skogstad, G. The Politics of Agricultural Policy Making in Canada. Toronto: University of Toronto Press, 1987. 
Skogstad, G. "The Two Faces of Canadian Agriculture in a Post-staples Economy," Canadian Review of Political Science, 1(1) (2007), 26-41.

Temperley, J. and L. Fragar, Rural Worker Safety Induction: A Practical Guide for Employers. Moree: Australian Centre for Agricultural Health and Safety, 2010.

Thompson, J. “Bringing in the Sheaves: The Harvest Excursionists, 1890-1928," Canadian Historical Review, 58(4) (1978), 467-498.

Thompson, J. and A. Seager, "Workers, Growers and Monopolists: The "Labour Problem" in the Alberta Beet Sugar Industry During the 1930s," Labour/Le Travailleur, 3 (1978), 153-174.

Thomson, G. "First Shot Fired in Battle of Electoral Boundaries," Edmonton journal. 22 March 2008. http://www2.canada.com/edmontonjournal/columnists/story.html?id=01d897febea5-4f48-9813-aa2e7669ce6d\&p=2 (28 September 2011).

Tompa, E., S. Treithick and C. McLeod, "Systematic Review of the Prevention Incentives of Insurance and Regulatory Mechanisms for Occupational Health and Safety," Scandinavian Journal of Work, Environment and Health, 33(2) (2007), 85-95.

Tucker, E. "Will the Vicious Circle of Precariousness be Unbroken? The Exclusion of Ontario Farm Workers from the Occupational Health and Safety Act," in L. Vosko (ed.), 256-276, Precarious employment. Montreal: McGill-Queen's University Press, 2006.

Tucker, E. "Farm Worker Exceptionalism: Past, Present and the post-Fraser Future.” In F. Faraday, J. Fudge and E. Tucker (eds) 30-56, Constitutional Labour Rights in Canada: Farm Workers and the Fraser Case, Toronto: Irwin, 2012.

Tullar, J., S. Brewer, B. Amick, E. Irvin, Q. Mahood, L. Pompeii, A. Wang, D. Van Eerd, D. Gimeno and B. Evanoff, "Occupational Safety and Health Interventions to Reduce Musculoskeletal Symptoms in the Health Care Sector," Journal of Occupational Rehabilitation, 20(2) (2010), 199-219.

United Food and Commercial Workers, "Harvest of Death Continues in Alberta". [Edmonton], 2010. 
United Food and Commercial Workers of Canada and the Agriculture Workers Alliance, “The Status of Migrant Farm Workers in Canada, 2010-2011”. [Rexdale], 2011.

Urban Renaissance Institute, Agricultural Subsidies in Canada, 1991-2001. [2002] http://urbanrenaissance.probeinternational.org/2002/06/13/agriculturalsubsidies-canada-1992-2001/ (15 October 2011).

Veeman, M. and T. Veeman, "Agriculture and Food," in J. March, ed., The Canadian Encyclopedia (Toronto 2011). http://www.thecanadianencyclopedia.com/index.cfm?PgNm=TCE\&Params=a1A

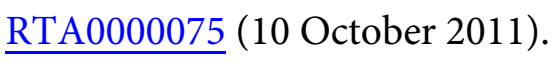

Verduzco, G. and M. Lozano, "Mexican Workers' Participation in CSAWP and Development Consequences in the Workers' Rural Home Communities.” NorthSouth Institute: Ottawa, 2003.

Vosko, L. "Precarious Employment: Towards an Improved Understanding of Labour Market Insecurity." In L. Vosko (ed), 3-42, Precarious Employment: Understanding Labour Market Insecurity in Canada, Montreal: McGill-Queen's University Press, 2006.

Waehrer, G. and T. Miller, "Does Safety Training Reduce Work Injury in the United States?" The Ergonomics Open Journal. 2 (2009), 26-39.

Weil, D. and A. Pyles. "Why Complain? Complaints, Compliance and the Problem of Enforcement in the US Workplace." Comparative Labor Law \& Policy Journal 27, no. 1 (2005): 59-92.

White, M. and E. Marsh, "Content Analysis: A Flexible Methodology," Library Trends, 55(1) (2005), 22-45.

Xuiwen, M., P. Entzel, Y. Men, R. Chowdhury and S. Schneider, "Effects of Safety and Health Training on Work-Related Injury Among Construction Laborers," Journal of Occupational and Environmental Science, 46(12) (2004), 1222-1228. 